\title{
Multigroup Moderation Test in Generalized Structured Component Analysis
}

\author{
Angga Dwi Mulyanto1, Solimun¹, Ni Wayan Surya Wardhani ${ }^{1}$, Suharno ${ }^{2}$ \\ ${ }^{1}$ Brawijaya University, Indonesia \\ ${ }^{2}$ Mercu Buana University, Indonesia
}

Email: angga.dwi.m@gmail.com

\begin{abstract}
Generalized Structured Component Analysis (GSCA) is an alternative method in structural modeling using alternating least squares. GSCA can be used for the complex analysis including multigroup. GSCA can be run with a free software called GeSCA, but in GeSCA there is no multigroup moderation test to compare the effect between groups. In this research we propose to use the T test in PLS for testing moderation Multigroup on GSCA. T test only requires sample size, estimate path coefficient, and standard error of each group that are already available on the output of GeSCA and the formula is simple so the user does not need a long time for analysis.
\end{abstract}

Keywords: GSCA, GeSCA, Multigroup Moderation Test

\section{INTRODUCTION}

In 2004, Hwang and Takane introduced an alternative method for path analysis called Generalized Structured Component Analysis (GSCA). GSCA can be used for data reflective and formative, can be used for recursive and non-recursive relationship, doesn't require normality assumption, and can be used for small sample size [1]. Differences and similarities GSCA with other method can see in Table 1.

Table 1. SEM, PLS and GSCA

\begin{tabular}{cccc}
\hline Criteria & SEM & PLS & GSCA \\
\hline Software & AMOS (purchase) & $\begin{array}{c}\text { SMART-PLS (free and } \\
\text { purchase) }\end{array}$ & GeSCA (free) \\
\hline $\begin{array}{c}\text { Outer } \\
\text { Model }\end{array}$ & Reflective & $\begin{array}{c}\text { Reflective and } \\
\text { Formative }\end{array}$ & $\begin{array}{c}\text { Reflective and } \\
\text { Formative }\end{array}$ \\
\hline Inner Model & $\begin{array}{c}\text { Recursive and Non- } \\
\text { Recursive }\end{array}$ & Recursive & $\begin{array}{c}\text { Recursive and Non- } \\
\text { Recursive }\end{array}$ \\
\hline
\end{tabular}

A few years later, Hwang and Takane created software for GSCA called GeSCA [2]. GeSCA already available for multigroup features but have not reached the multigroup moderation test. Multigroup moderation test used to compare the effect between groups [3]. In 2000, Chin introduced multigroup moderation test using T test on PLS [4]. In this research we want to try T test for multigroup moderation on GSCA. 


\section{THEORITICAL REVIEW}

The Formula for multigroup moderation test using $\mathrm{T}$ test if standard deviations are equal can be write as [3]

$$
t=\frac{\left|b_{1}-b_{2}\right|}{\sqrt{\frac{\left(n_{1}-1\right)^{2}}{n_{1}+n_{2}-2} S E_{1}^{2}+\frac{\left(n_{2}-1\right)^{2}}{n_{1}+n_{2}-2} S E_{2}^{2}} \times \sqrt{\frac{1}{n_{1}}+\frac{1}{n_{2}}}} \sim t_{n_{1}+n_{2}-2}
$$

If standard deviations are unequal, the formula can be write as [3]

$$
t=\frac{\left|b_{1}-b_{2}\right|}{\sqrt{\frac{n_{1}-1}{n_{1}} S E_{1}^{2}+\frac{n_{2}-1}{n_{2}} S E_{2}^{2}}}
$$

Degree of freedom for standard deviations are unequal can be write as [3]

$$
d f=\left\|\frac{\left(\frac{n_{1}-1}{n_{1}} S E_{1}^{2}+\frac{n_{2}-1}{n_{2}} S E_{2}^{2}\right)^{2}}{\frac{n_{1}-1}{n_{1}^{2}} S E_{1}^{4}+\frac{n_{2}-1}{n_{2}^{2}} S E_{2}^{4}}-2\right\|
$$

With

$b_{1} \quad$ : estimate for path coefficient group 1

$b_{2} \quad$ : estimate for path coefficient group 2

$\mathrm{n}_{1} \quad$ : sample size group 1

$\mathrm{n}_{2} \quad$ : sample size group 2

$\mathrm{SE}_{1} \quad$ : standard error group 1

$\mathrm{SE}_{2} \quad$ : standard error group 2

To know that standard deviations are equal or unequal, we can use Bartlett test. Formula Bartlett test for moderation multigroup can be write as [5]

$$
\chi^{2}=\frac{(n-k) \ln s_{p}^{2}-\sum_{i=1}^{k}\left(n_{i}-1\right) \ln s_{i}^{2}}{1+\left(\frac{1}{3(k-1)}\right)\left(\left(\sum_{i=1}^{k} \frac{1}{n_{i}-1}\right)-\frac{1}{n-k}\right)} \sim \chi^{2}{ }_{k-1}
$$

$\mathrm{k}$ is the number of group and $\mathrm{n}$ is the total of sample size. Because $\mathrm{T}$ test can only use for 2 group, equation 4 can rewrite as

with

$$
\chi^{2}=\frac{(n-2) \ln s_{p}^{2}-\left(\left(n_{1}-1\right) \ln s_{1}^{2}+\left(n_{2}-1\right) \ln s_{2}^{2}\right)}{1+\left(\frac{1}{3}\right)\left(\frac{1}{n_{1}-1}+\frac{1}{n_{2}-1}-\frac{1}{n-2}\right)} \sim \chi_{1}^{2}
$$

\section{RESEARCH METHOD}

The steps of this research are as follows:

1. Collecting Data

A primary data was collected through questionnaires for 4 latent variables to measure the effect of performance expectancy, effort expectancy and social influence on behavioral intention using e-learning with gender as a moderator variable. Sample size in this research is 52 males and 48 female students from Mercubuana University. 
2. GSCA

The second step is structural modeling with GSCA using GeSCA software. The user can access www.sem-gesca.org to run GSCA.

3. Bartlett Test

After obtained the results of GSCA, the third step is compare standard deviation group 1 and group 2 using equation 5. If standard deviation group 1 equal with standard deviation group 2 (p-value $\geq 0.05$ ) we can use T Test in Equation 1, and if standard deviation group 1 unequal with standard deviation group 2 ( $\mathrm{p}$-value $<0.05$ ) we can use T Test in Equation 2.

4. Multigroup Moderation Test

The last step is Multigroup Moderation Test using T Test according the results of Bartlett Test. If $p$-value $\geq 0.05$ then the effect of group 1 similar with the effect of group 2 , else if $p$-value $<0.05$ then the effect of group 1 difference with the effect of group 2 .

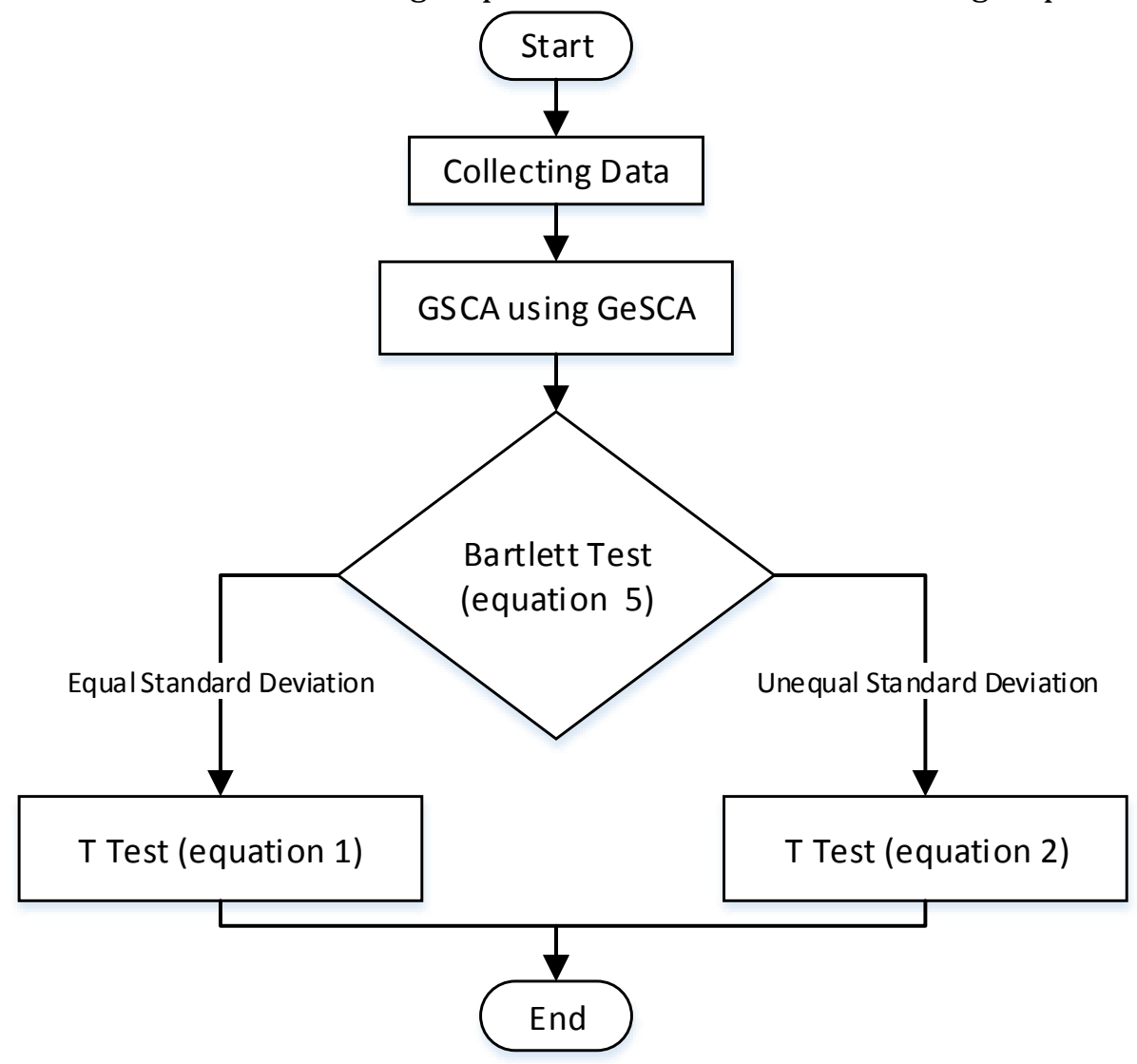

Figure 1. Steps of Research

Model of this research is the part of Unified Theory of Acceptance and Use of Technology (UTAUT) can see in figure 2 [6]. 


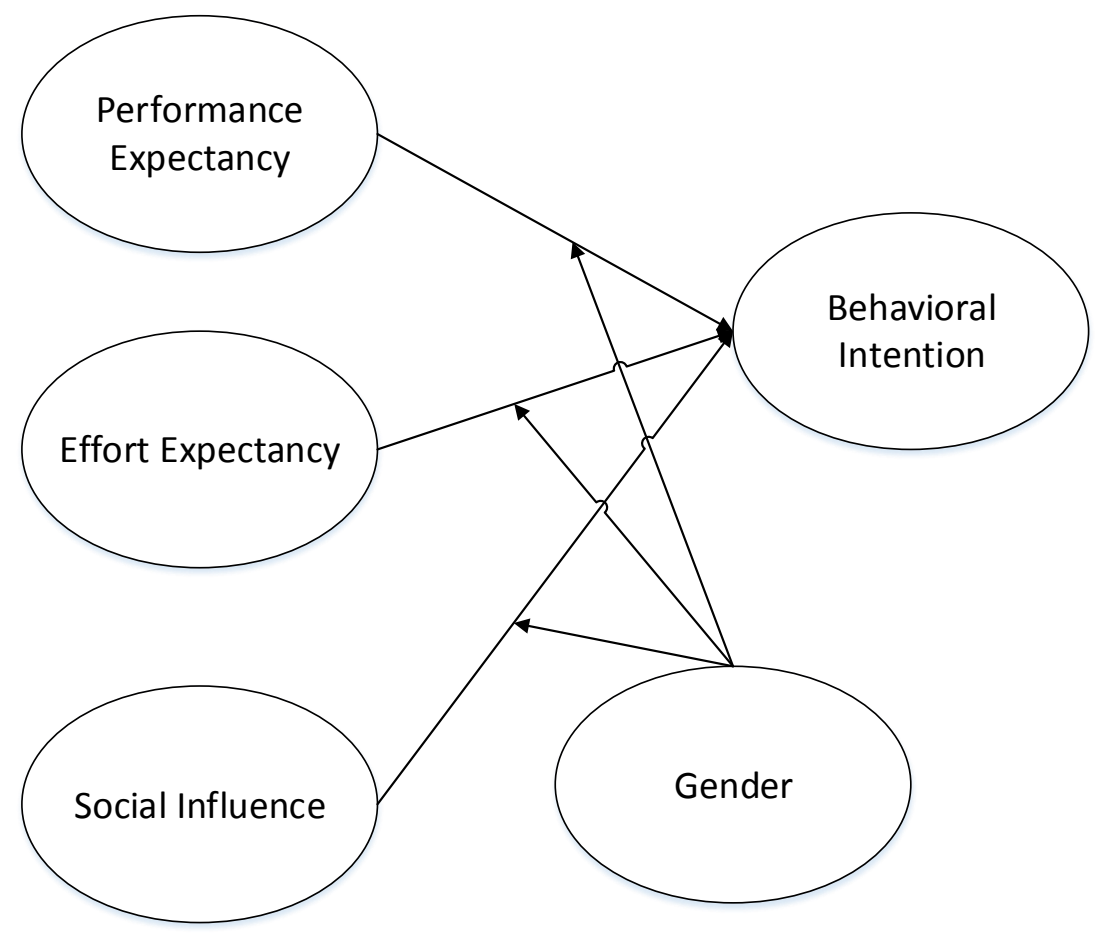

Figure 2. Research Model

\section{RESULTS AND DISCUSSION}

The first step is Generalized Structured Component Analysis with GeSCA software. The Result of GSCA can see in table 2.

Table 2. Result of GSCA

\begin{tabular}{lrrrrrr}
\hline \multirow{2}{*}{ Path } & \multicolumn{2}{c}{ Group 1 } & \multicolumn{3}{c}{ Group 2 } \\
\cline { 2 - 7 } & Estimate & \multicolumn{1}{c}{ SE } & \multicolumn{1}{c}{ CR } & Estimate & SE & \multicolumn{1}{c}{ CR } \\
\hline $\begin{array}{l}\text { performance expectancy }> \\
\text { behavioral intention }\end{array}$ & 0.205 & 0.183 & 1.12 & 0.038 & 0.22 & 0.17 \\
$\begin{array}{l}\text { effort expectancy }>\text { behavioral } \\
\text { intention }\end{array}$ & 0.19 & 0.161 & 1.18 & 0.122 & 0.188 & 0.65 \\
\hline $\begin{array}{l}\text { social influence }>\text { behavioral } \\
\text { intention }\end{array}$ & 0.379 & 0.173 & $2.19^{*}$ & 0.539 & 0.176 & $3.06^{*}$ \\
\hline CR* $=$ significant at $\mathbf{0 . 0 5}$ level & & & & & & \\
\hline
\end{tabular}

As we can see from Table 2, performance expectancy and effort expectancy has no effect on behavioral intention both male and female. Only social influence has effect on behavioral intention both male and female.

After get the result of GSCA (Estimate path coefficient and Standard Error of two groups), we can proceed to second step. The second step is Bartlett test (equation 5) to know standard deviations are equal or unequal.

Table 3. Result of Bartlett Test

\begin{tabular}{lccc}
\hline \multicolumn{1}{c}{ Path } & \multicolumn{2}{c}{ Bartlett Test } \\
\cline { 2 - 4 } & $\chi^{2}$ & P-value & Information \\
\hline $\begin{array}{l}\text { performance expectancy }>\text { behavioral } \\
\text { intention }\end{array}$ & 0.994875 & 0.318554 & standard deviation equal \\
\hline
\end{tabular}




\begin{tabular}{llll}
\hline effort expectancy $>$ behavioral intention & 0.632093 & 0.426589 & standard deviation equal \\
\hline social influence $>$ behavioral intention & 0.027056 & 0.869347 & standard deviation equal \\
\hline
\end{tabular}

As we can see from Table 3 that both groups have the same standard deviation in all paths, so for multigroup moderation test we can use equation 1 .

Table 4. Result of T Test (Multigroup Moderation Test)

\begin{tabular}{lcll}
\hline \multicolumn{1}{c}{ Path } & \multicolumn{2}{c}{ T Test } \\
\cline { 2 - 4 } & $\mathrm{T}$ & P-value & \multicolumn{1}{c}{ Information } \\
\hline $\begin{array}{l}\text { performance expectancy }>\text { behavioral } \\
\text { intention }\end{array}$ & 0.592964 & 0.554571 & $\begin{array}{l}\text { Both group have the same } \\
\text { effect }\end{array}$ \\
\hline effort expectancy $>$ behavioral intention & 0.278817 & 0.780973 & $\begin{array}{l}\text { Both group have the same } \\
\text { effect }\end{array}$ \\
\hline social influence $>$ behavioral intention & 0.654298 & 0.514452 & $\begin{array}{l}\text { Both group have the same } \\
\text { effect }\end{array}$ \\
\hline
\end{tabular}

Based on Table 4, we can say that there is no difference between male and female in all paths or in other word we can say that Gender is not a moderator variable that moderate the effect of performance expectancy, effort expectancy and social influence on behavioral intention using e-learning.

\section{CONCLUSION}

$\mathrm{T}$ test only requires estimate path coefficient, sample size and standard error of each group, so it can be used as an alternative test to compare the effect between group in Generalized Structured Component Analysis. Limitations of the T test can only be used to compare the 2 groups.

The results of this research indicate difference with UTAUT, male and female have similar effect and only social influences which have an effect on behavioral intention on e-learning. To increases behavioral intention using e-learning in male or female student, Mercu Buana University need more social approach to students. Sosial approach can through persuasion from lecturer to student or student to student.

\section{REFERENCE}

[1] H. Hwang and Y. Takane, "Generalized structured component analysis," Psychometrika, vol. 69, no. 1, pp. 81-99, 2004.

[2] H. Hwang, GeSCA User's Manual, Online User Manual, 2011.

[3] M. Sarstedt, J. Henseler and M. Christian, "Multigroup Analysis in Partial Least Squares (PLS) Path Modeling: Alternative Methods and Empirical Results," Measurement and research methods in international marketing, advances in international marketing, vol. 22, pp. 195-218, 2011.

[4] W. W. Chin, Frequently asked questions - partial least squares and PLS-graph, Online User Manual, 2000.

[5] NIST/SEMATECH, e-Handbook of Statistical Methods, Online User Manual, 2012.

[6] V. Venkatesh, M. G. Morris, G. B. Davis and F. D. Davis, "User acceptance of information technology: Toward a unified view," MIS quarterly, pp. 425-478, 2003. 